\title{
Optimization of Solvent Based-Dyes by Using Lady's Mantle and Zinc Borate
}

\author{
Nil Acaralı*, Tugba Çıfte \\ Yildiz Technical University, Chemical Engineering Department, Davutpasa St., No:127, \\ 34210, Esenler, Istanbul, Turkey.: \\ nilbaran@gmail.com \\ *Corresponding author
}

Received: 19 January 2017

Accepted: 29 June 2017

DOI: $10.18466 /$ cbayarfbe.339347

\begin{abstract}
This study aimed to improve the physical properties of dyes by adding various additives in solvent based dyes for some sectors such as metal industry and wood preservation. The physical tests as viscosity, hydrophobicity, drying time, hiding power/transparency were applied on surfaces. Taguchi optimization method was used to determine the most effective parameters and the characterization of molecular bonds was investigated with FTIR. It is observed that the lady's mantle develops the hydrophobic property and the pumice increased the adhesive effect of dye. According to the test results the additives did not affect the glossiness, color availability and drying time as a negative result. When the dyes prepared were compared reference dyes, it was seen that hydrophobicity and hiding power/transparency effects were increased. FT-IR spectra showed that the dyes prepared had similar bonds with reference dyes.
\end{abstract}

Keywords: Solvent, Taguchi, FT-IR, Hydrophobicity, Dye

\section{Introduction}

Boron is the one of the indispensable mineral resources having strategic importance and one of the main input materials of the growing industrial and technological progress. Each boron compounds is used for specific purposes in different sectors [1]. There are approximately 15 boron minerals that have economic value although more than 200 boron minerals are known. Important boron mineral reserves are gathered in a few places around the world and more than two thirds of them are in Turkey [2]. Increasing usage of additives as a flame retardant or smoke inhibitor in plastics, woods, textile products, dyes, and construction materials is expected to decrease the loss of life and material in fire disasters. So some boron compounds are used as a fire retardant such as boric acid, zinc borate, barium metaborate, boron phosphates, fluoroborates etc. [3].

Pumice is a natural volcanic rock that is used in different industrial fields as a raw material $[4,5]$. In current technology, the usage of pumice stone shows a gradually rising trend in different industrial areas. In majority, it is used as a lightweight building material in civil structuring sector [6]. Main countries in which pumice deposits are high are
U.S.A, Turkey, and Italy. In Turkey pumice deposits are around 2,8 billion tons [7]. Dyes are available to provide different qualities wherever human life exists. According to usage areas the distributions of the current installed capacity of Turkey's dye sector are generally construction dyes, wooden furniture dyes, metal dyes, otomotive dyes, etc. [8]. The main difference between the dyes is the resin or polymers used as binders [9]. So the dyes have decorative and protective properties due to the components they include [10].Taguchi method is mainly used in the optimization of industrial processes and products [11].

Taguchi's optimization technique is a unique and powerful optimization discipline that allows optimization with minimum number of experiments. The Taguchi experimental design reduces cost, improves quality, and provides robust design solutions [12]. The advantages of Taguchi method over the other methods are that numerous factors can be simultaneously optimized and more quantitative information can be extracted from fewer experimental trials [13].

In this study, unlike the studies in the literature, pumice, 
lady's mantle and zinc borate were grinded and homogenized with adding to dye by using an appropriate polymeric binder. The optimum parameters were determined by using Taguchi method for 3 parameters and 3 levels. In conclusion, it was seen that the usage of additives effected the physical properties of solvent based-dyes.

\section{Experımental Method}

\subsection{Materials}

The materials and chemicals used in this study were pumice (from Nevsehir region), zinc borate (Çolakoğlu A.Ş), lady's mantle, solvent based-dye, aluminium plates (10x10 cm), applicator (TQC-Bird Film Applicators 4- Sided).

\subsection{Additive Preparation}

Pumice, zinc borate were brought to small particle size (+200 mesh) with using ball mill. Lady's mantle as a herbal resource was grinded by using some equipments and sieve.

\subsection{Experimental Study}

The pumice, zinc borate and lady's mantle were used in range of $0-15 \%$ (in terms of dye, w/w). The dye, pumice, zinc borate and lady's mantle were stirred by using mechanical stirrer (1000 rpm-3 min). The applicator film thickness was used with $150 \mu \mathrm{m}$ (Figure 1).

Zebra papers (the surface chequered with black and white colours) were used for the visual tests. Dyes samples were prepared according to Taguchi optimization method. In this study, 3 parameters (zinc borate, pumice and lady's mantle) and 3 levels were used given in Table 1 .

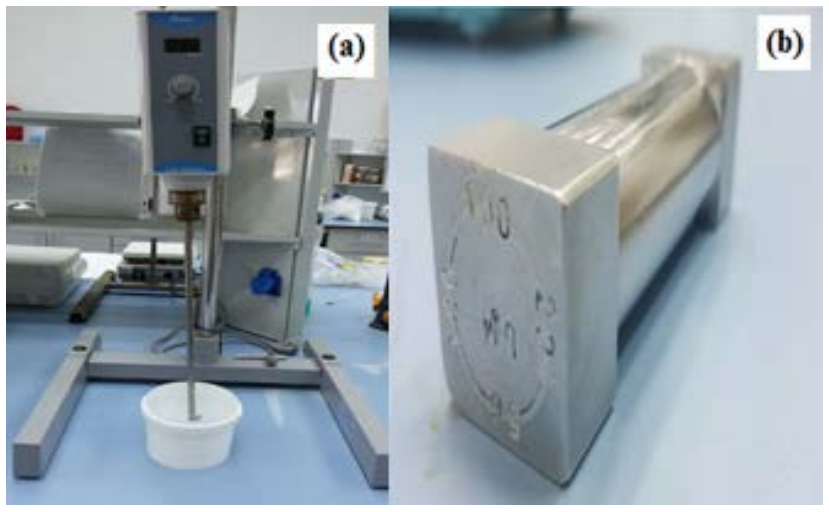

Figure 1: Equipments: (a) Mechanical stirrer, (b) Aplicator

Table 1. Experimental levels

\begin{tabular}{|c|l|c|c|c|}
\hline \multicolumn{2}{|c|}{ Parameters } & Level 1 & Level 2 & Level 3 \\
\hline 1 & Lady's Mantle & $\mathrm{LM}_{1}$ & $\mathrm{LM}_{2}$ & $\mathrm{LM}_{3}$ \\
\hline 2 & Zinc Borate & $\mathrm{Z}_{1}$ & $\mathrm{Z}_{2}$ & $\mathrm{Z}_{3}$ \\
\hline 3 & Pumice & $\mathrm{P}_{1}$ & $\mathrm{P}_{2}$ & $\mathrm{P}_{3}$ \\
\hline
\end{tabular}

Letters in level section (LM, Z and P) represent amount of additives and changed $0-6 \%(\mathrm{w} / \mathrm{w})$.
Table 2. L-9 Orthogonal array for solvent based-dyes

\begin{tabular}{|c|c|c|c|}
\hline No & Lady' Mantle & Zinc Borate & Pumice \\
\hline 1 & 1 & 1 & 1 \\
\hline 2 & 1 & 2 & 2 \\
\hline 3 & 1 & 3 & 3 \\
\hline 4 & 2 & 1 & 2 \\
\hline 5 & 2 & 2 & 3 \\
\hline 6 & 2 & 3 & 1 \\
\hline 7 & 3 & 1 & 3 \\
\hline 8 & 3 & 2 & 1 \\
\hline 9 & 3 & 3 & 2 \\
\hline
\end{tabular}

Taguchi Optimization Method L-9 orthogonal array was given in Table 2 for additives. According to Table 2, sample 1 was reference solvent based-dye and other samples were prepared with additive agents.

\subsection{Characterization}

The FT-IR (Bruker-Tensor 27) analysis was performed to characterize the raw materials and compare the literature. The major structural groups were detected from their infrared patterns. The tests as cross-cut adhesion test, visual tests, and hydrophobicity were carried out on metal surfaces.

\section{Results And Discussion \\ 3.1. Optimization Results}

Taguchi method have a special design of orthogonal arrays which describes the experiment plan on the basis of degrees of freedom [14]. For the Taguchi design and analysis of results Minitab Release 13.20 Statistical Software was used after determined parameters. In this study, Taguchi's L-9 orthogonal array table was used to carry out experiments by choosing three parameters at three levels (Table 2).

In the orthogonal array of L-9 type, $\mathrm{L}$ and subscript 9 means Latin square and the number of experiments respectively. A full factorial approach will require 27 experiments to be conducted for optimizing a process while in fractional factorial using an L-9 orthogonal array the number of experiments is reduced to nine. The optimum experiment was No: 5 as given Table 2.

\subsection{FT-IR Analysis Results}

Infrared spectroscopy is a standard method of analytical pharmacy and chemistry which provides the images of vibration of atoms of compound [15].

When IR radiations passed from a sample, some of it is absorbed by the sample and the remaining passed through. A spectrometer of full range (500-2500) nanometer was 
used to acquire reflectance signatures of samples in laboratory [16]. FTIR peaks are relatively narrow and in many cases can be associated with the vibration of a particular chemical bond (or a single functional group) in the molecule [17].

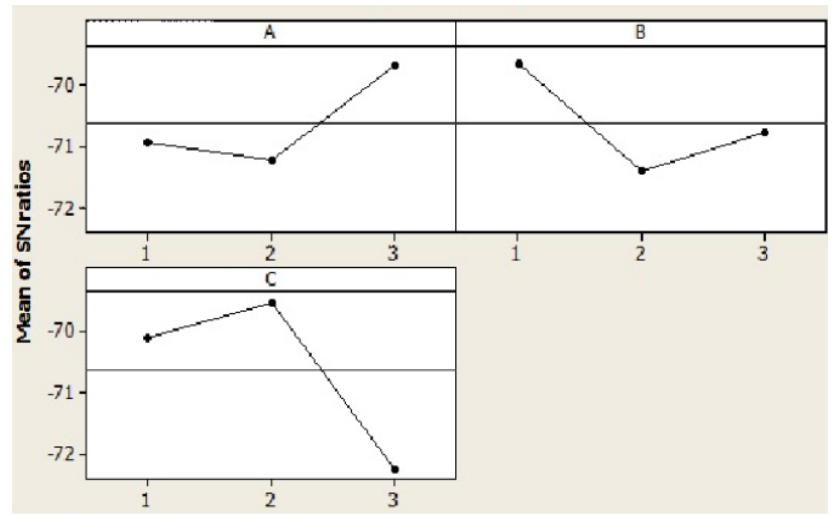

Figure 2. S/N ratio in Taguchi Method.

An FT-IR spectrum of reference dye was shown in Figure 3. The C-O stretching band was observed at around 1700 $\mathrm{cm}^{-1}$ and $1000 \mathrm{~cm}^{-1}$ in the FT-IR spectrum of pumice as specific two peaks [18]. OH (3700-3000 $\left.\mathrm{cm}^{-1}\right)$ and aliphatic $\mathrm{CH}\left(3000-2800 \mathrm{~cm}^{-1}\right)$ The quantity of the aromatic $\mathrm{CH}$ groups $\left(1000-700 \mathrm{~cm}^{-1}\right)$ was approximately the same as previous study [19].

In addition, it was seen that the chemical structure of dye prepared at optimum point was similar with reference solvent based-dye due to being physical mixture (Figure 3, Figure 4).

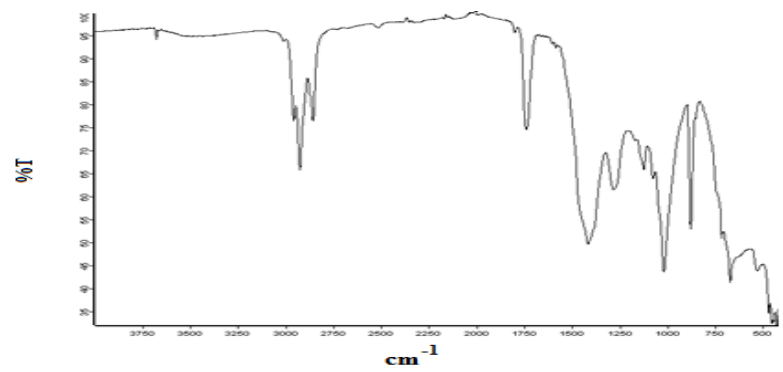

Figure 3. FT-IR spectrum of reference dye.

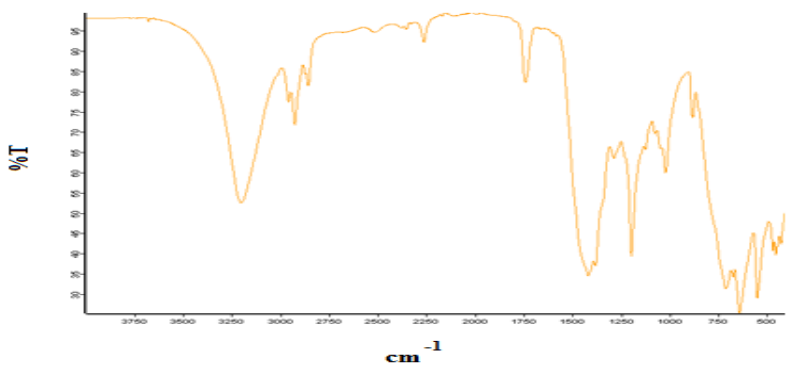

Figure 4. FT-IR spectrum of dye (No:5).

\subsection{Cross-cut Adhesion Test}

Dyed surfaces were divided either six or eleven cuts in each direction and pressure sensitive tape was applied over the aluminium surfaces.

According to the test results it was seen that the additives improved the resistance of the dye adhesion. The dye (No:5) showed the best adhesion resistance. Referance dye showed more weaker resistance than dyes which include pumice and zinc borate. Lady's mantle didn't contribute to any properties related with adhesion. Experimental results were given in Figure 5.

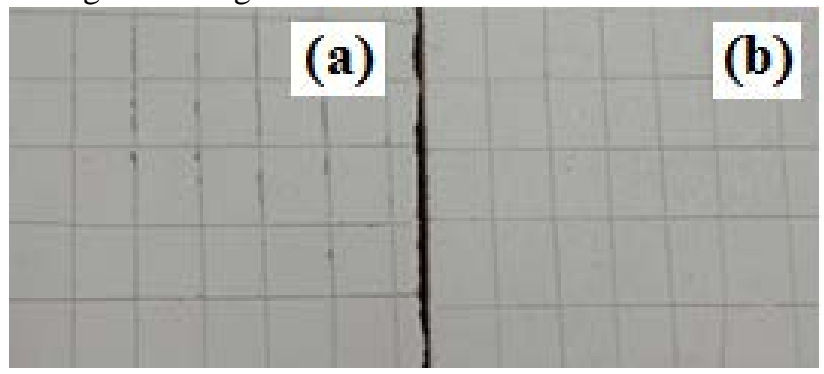

Figure 5: Cross cut adhesion test: (a) Reference dye, (b) Dye (No:5).

\subsection{Visual test}

Zebra papers were used to compare the covering power of dyes. According to visual test results dyes prepared had concealer property for walls and decorative due to its offwhite colour (Figure 6).

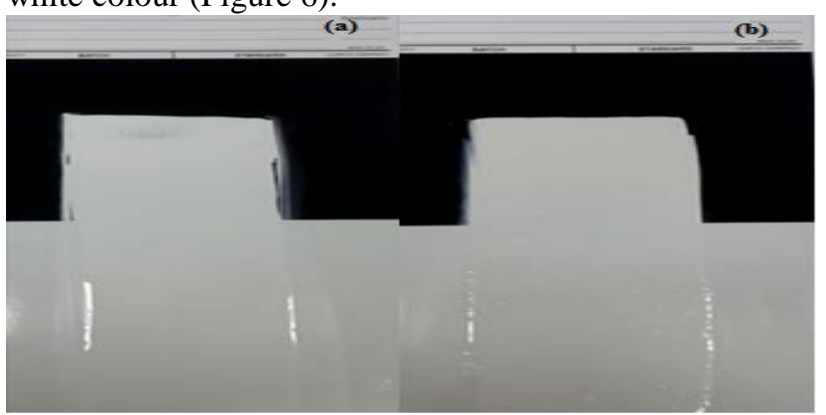

Figure 6. Visual test: (a) Reference dye, (b) Dye (No:5).

\subsection{Hydrophobicity Test}

For solid surfaces the wettability is an important topic for material science and fundamental researchs because their various potential applications, intensive researches have been done in recent years [20]. Materials with a special affinity for water those it spreads across, maximizing contact are known as hydrophilic. Those that naturally repel water, causing droplets to form, are known as hydrophobic. Hydrophilic and hydrophobic materials are defined by the geometry of water on a flat surface specifically, the angle between a droplet's edge and the surface underneath it [21]. Water was dropped on the dry coating film a period of time 
as a volume of $0,1 \mathrm{ml}$ pipette. As a result, surface was hydrophobic in the dry dye film (Figure 7).

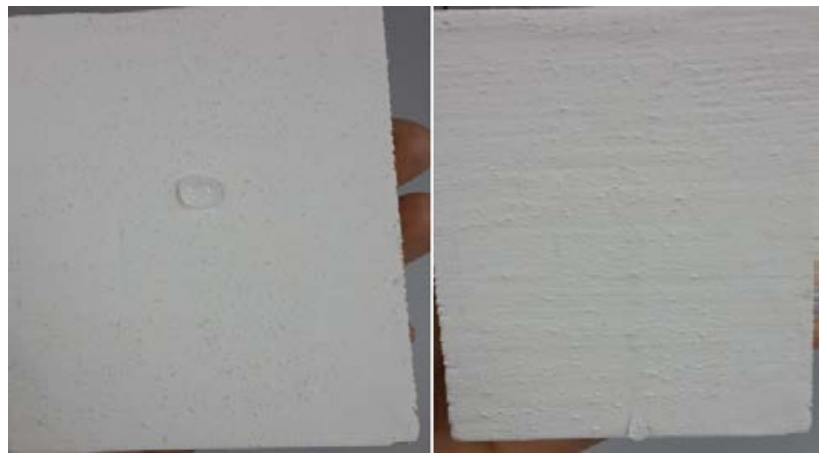

Figure 7. Hydrophobicity test result for No:5

\section{Conclusion}

Consequently, in this study, the physical effects of zinc borate, lady's mantle and pumice introduced into the paint were investigated. Therefore, 9 different contents are prepared by selecting 3 parameters and 3 levels according to Taguchi L9 orthogonal array. The optimum mixture was experiment 5 for 2-2-3 in Taguchi method. According to classification of additives; lady' mantle provided hydrophobic properties for dyes, pumice enhanced the adhesion strenght of dyes, zinc borate did not improve significantly any physical properties of dyes.

\section{References}

1. Aydın, D. Y; Gürü, M; Ayar, B; Çakanyıldırım, Ç. Bor Bileşiklerinin Alev Geciktirici ve Yüksek Sıcaklığa Dayanıklı Pigment Olarak Uygulanabilirliği. Journal of Boron. 2016; 1, 33-39.

2. Kalafatoğlu, İ. E; Örs, S. N. 21. Yüzyılda Bor Teknolojileri ve Uygulamaları. BAÜ Fen Biimleri. Enstitüsü Dergisi. 2003; 5(1), 59-71.

3. Durğun, Z. G. Ceşitli Kalsiyum Boratların Sentezi Karakterizasyonu ve Alev Geciktirici Etkinliklerinin İncelenmesi. MSc Thesis. Ankara University. 2010.

4. Ebrahimi, S; Morghei, M. Formaldehyde Biodegradation Using an İmmobilized Bed Aerobic Bioreactor with Pumice Stone as a Support. Scientia Iranica. 2011; 18(6), 1372-1376.

5. Baspınar, E; Gündüz, L. İnşaat Endüstrisinde Kullanılan Pomza Agregalarının Mineralojik ve Petrografik Özellikleri, IV. Ulusal Kırmataş Sempozyumu, Istanbul, Turkey, December 2-4, 2006.

6. Gündüz, L; Yılmaz, İ. Orta Anadolu Pomza Oluşumlarının Endüstriyel Olarak Kullanılabilirlik Ölçütleri, Türkiye 17. Uluslararası Madencilik Kongresi ve Sergisi-TUMAKS, June 19-22, 2001.
7. Elmastas, N. A Mine Becoming Increasingly Important or Economy of Turkey: Pumice. The Journal of International Social Research. 2012; 5(23), 197-206.

8. Koltka, S; Sabah, E. Paint Industry and Precipitated Calcium Carbonate (PCC), 8. Uluslararası Endüstriyel Hammaddeler Sempozyumu, Istanbul, Turkey, November 29-30, 2012.

9. Alıcılar, A; Ökenek, F; Kayran, B; Tutak, M. Bor Katkılı Stiren Akrilik Boyaların Alev Geciktirme Duman Bastırma ve Antibakteriyel Etkinlikleri. Journal of the Faculty of Engineering and Architecture of Gazi University. 2015; 30(4), 701-709.

10. Sengül, F; Dursun, D; Catalkaya, E. C; Dinçer, A. R; Kargı, F. Solvent İçerikli Boya Sanayi Atıksularının Arıtımı. Çevre Bilim ve Teknoloji. 2003; 1(3), 1-9.

11. Bădescu, D; Grigore, V; Deneșa, C; Bădescua, M. The Taguchi Method and Conditions for its Implementation in High Performance Athletic Training. Procedia-Social and Behavioral Sciences. 2014; 117, 378382.

12. Tanabe, I; Sakamoto, H; Miyamoto, K. Development of Innovative Tool Using Taguchi-methods. AASRI Procedia. 2014; 9, 107-113.

13. Pundir, R; Chary, G.H.V.C; Dastidar, M.G. Application of Taguchi Method for Optimizing the Process Parameters for the Removal of Copper and Nickel by Growing Aspergillus sp. Water Resources and Industry. 2016; Article in press, dx.doi.org/10.1016/j.wri.2016.05.001.

14. Singh, P.K; Patel, D; Prasad, S.B. Optimization of Process Parameters during Vibratory Welding Technique using Taguchi's Analysis. Perspectives in Science. 2016; 8, 399-402.

15. Dole, M. N; Patel, P. A; Sawant, S. D; Shedpure, P.S. Advance Applications of Fourier Transform Infrared Spectroscopy. International Journal of Pharmaceutical Sciences Review and Research. 2011; 7(2), 159-166.

16. Younis, S. M. Z; Iqbal, J. Estimation of Soil Moisture using Multispectral and FTIR Techniques. The Egyptian Journal of Remote Sensing and Space Sciences. 2015; 18, 151-161.

17. Movasaghi, Z; Rehman, S; Rehman, I. Fourier Transform Infrared (FTIR) Spectroscopy of Biological Tissues. Applied Spectroscopy Reviews. 2008; 43, 134-179.

18. Ozturk Akbal, F., Akdemir, N. and Nur Onar, A. (2000) FT-IR Spectroscopic Detection of Pesticide After Sorption Onto Modified Pumice. Talanta; 53(1), 131-135.

19. Varhegyi, G., Szabo, P., Till, F. and Zelei, B. (1998) TG, TG-MS and FTIR Characterization of High-Yield Biomass Charcoals, Energy Fuels. 12, 969-974.

20. Bağçeci, B. İ. Nano Partikül Yüzey Kaplama. MSc Thesis. Gazi University. 2010

21. http://news.mit.edu/2013/hydrophobic-and-hydrophilic-explained$\underline{0716 .}$ 